\title{
Mast cell tryptase promotes breast cancer migration and invasion
}

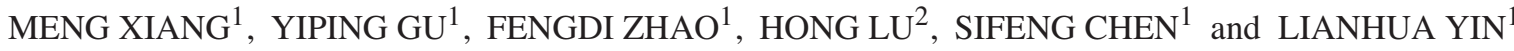 \\ Departments of ${ }^{1}$ Physiology and Pathophysiology, and ${ }^{2}$ Biochemistry, \\ Shanghai Medical College, Fudan University, Shanghai 200032, P.R. China
}

Received October 1, 2009; Accepted November 3, 2009

DOI: 10.3892/or_00000676

\begin{abstract}
It has been reported that the number of typtasepositive mast cells was significantly greater in breast peritumoral tissue. However, the significance of tryptase in tumor growth and metastasis is unknown. Tryptase in surgical breast cancer samples was stained by immunohistochemistry. The effects of tryptase on breast cancer proliferation, invasion and migration were observed in vitro. We found significantly more tryptase in peritumoral tissue than in normal breast tissue. The increased tryptase was associated with higher tumor grade and more lymph node metastasis. Tryptase promoted the invasion and migration of breast cancer cells along with activation of matrix metalloproteinase-2. Tryptase did not affect the proliferation of the cells. Our results indicate that tryptase promotes breast cancer migration and invasion.
\end{abstract}

\section{Introduction}

Mast cells (MCs) regulate extracellular matrix degradation, angiogenesis and immune response by releasing numerous bioactive substances. There are at least two types of human MCs. Connective tissue mast cells contain tryptase and chymase (TC mast cells) while mucosal mast cells contain tryptase only (T mast cells) (1). They differ in the number and the type of secretory granules as well as their responsiveness to stimulation. MCs have been found to accumulate in the stroma of certain tumors (2). Kankkunen et al observed significantly more tryptase-containing MCs in malignant breast carcinomas than benign lesions (3). MC density has been associated with cancer growth by promoting angiogenesis (4). Mast cell-deficient mice are less susceptible to carcinogenic agents (5). Therefore, exploring an individual $\mathrm{MC}$ component that is responsible for the pathogenesis of tumor progressiveness may provide new diagnostic markers and therapeutic targets for certain cancers.

Correspondence to: Dr Sifeng Chen or Dr Lianhua Yin, Department of Physiology and Pathophysiology, Shanghai Medical College, Fudan University, Shanghai 200032, P.R. China

E-mail: chen1216@fudan.edu.cn

E-mail: lhyin@shmu.edu.cn

Key words: tryptase, breast cancer, metastasis, matrix metalloproteinase-2, mast cell
Tryptase is a serine protease that represents approximate $50 \%$ of the total proteins in the MC granule (6). Tryptase promotes leukocyte migration and infiltration. Tumor invasion and metastasis share many features with the migration and infiltration of leukocytes. The present study aimed to observe the distribution of tryptase in malignant breast lesions and its relation with tumor grade and metastasis. We further analyzed the effects of tryptase on the proliferation and metastasis of breast cancer cells.

\section{Materials and methods}

Reagents. (3-(4,5-dimethylthiazol-2-yl)-2,5-diphenyltetrazolium bromide) (MTT), thymine deoxyriboside and Transwell $^{\mathrm{TM}}$ Permeable Supports for 24-well plates were purchased from Dojindo (Kumamoto, Japan), Sigma Chemical Co. (St. Louis, MO) and Corning (Life Sciences, Acton, MA), respectively. Tryptase was prepared as described previously (6).

Patient profiles and surgical specimens. Surgical specimens were collected from 80 breast cancer patients who underwent therapeutic surgery. The specimens were fixed with $10 \%$ neutral-buffered formalin and embedded in paraffin. Sections of the paraffin-embedded tissue were stained with hematoxylin-eosin (H\&E) for the histopathological diagnosis according to the Scarff-Bloom-Richardson histological grade system. All patients were female with a median age of 55.2 years. Eight samples from benign epithelia adjacent to malignant tissue served as normal control. The clinical and histological data of the patients are summarized in Table I.

Immunohistochemistry (IHC) assay. Paraffin tissue cores of the samples were used to construct a single tissue microarray (TMA) block with duplication of each sample (Shanghai Outdo Biotech Co., Ltd., Shanghai, China). Five-micrometer TMA sections were deparrafinized and rehydrated followed by antigen retrieval with EDTA at $\mathrm{pH} 8.0$ for $3 \mathrm{~min}$ in a

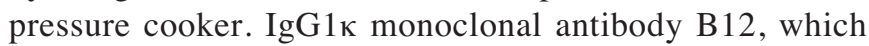
recognizes a conformational epitope of tryptase, was prepared as described previously (7) and used as the primary antibody in the immunohistochemical staining. The same TMA was counterstained with hematoxylin. The cumulative area of tryptase-positive spots of each sample in the TMA was measured using a Leica DMIL microscope (Leica Microsystems GmbH, Wetzlar, Germany). 
Table I. Clinical and pathological data of the patients.

\begin{tabular}{|c|c|c|}
\hline Patient characteristic & No. of case & $\%$ of all patients \\
\hline \multicolumn{3}{|l|}{ Pathological diagnosis } \\
\hline Infiltrating ductal & 49 & 61 \\
\hline Medullary carcinoma & 7 & 9 \\
\hline Infiltrating lobular & 8 & 10 \\
\hline Tubular carcinoma & 7 & 9 \\
\hline Mucinous carcinoma & 9 & 11 \\
\hline \multicolumn{3}{|l|}{ Age } \\
\hline$\leq 50$ & 31 & 39 \\
\hline$>50$ & 49 & 61 \\
\hline \multicolumn{3}{|c|}{$\begin{array}{l}\text { Histological grade and lymph } \\
\text { node metastasis of each grade }\end{array}$} \\
\hline 1 & 23 & 29 \\
\hline No & 17 & 21 \\
\hline $\mathrm{N} 1, \mathrm{~N} 2, \mathrm{~N} 3$ & 6 & 8 \\
\hline 2 & 36 & 45 \\
\hline No & 21 & 26 \\
\hline $\mathrm{N} 1, \mathrm{~N} 2, \mathrm{~N} 3$ & 15 & 19 \\
\hline 3 & 21 & 26 \\
\hline No & 0 & 0 \\
\hline $\mathrm{N} 1, \mathrm{~N} 2, \mathrm{~N} 3$ & 21 & 26 \\
\hline \multicolumn{3}{|c|}{ Total lymph node metastasis } \\
\hline NO & 38 & 48 \\
\hline $\mathrm{N} 1, \mathrm{~N} 2, \mathrm{~N} 3$ & 42 & 52 \\
\hline \multicolumn{3}{|l|}{ Hormonal receptors } \\
\hline $\mathrm{ER}^{+}, \mathrm{PR}^{+}$ & 44 & 55 \\
\hline $\mathrm{ER}^{+}, \mathrm{PR}^{-}$ & 5 & 6 \\
\hline $\mathrm{ER}^{-}, \mathrm{PR}^{+}$ & 11 & 14 \\
\hline $\mathrm{ER}^{-}, \mathrm{PR}^{-}$ & 20 & 25 \\
\hline
\end{tabular}

$\mathrm{N} 0, \mathrm{~N} 1, \mathrm{~N} 2$ and $\mathrm{N} 3$ represent lymph node negative (N0) and tumor metastasis to movable ipsilateral axillary lymph node (N1), ipsilateral axillary lymph node(s) fixed to one another or to other structures (N2) and ipsilateral internal mammary lymph node (N3), respectively. ER, estrogen receptor; PR, progesterone receptor.

Cell culture. The human breast carcinoma cell line MDA-MB231 was obtained from Shanghai Institute of Cell Biology, Chinese Academy of Sciences (Shanghai, China). The cells were cultured in Dulbecco's modified Eagle's medium supplemented with $10 \%$ heat-inactivated fetal bovine serum (FBS) at $37^{\circ} \mathrm{C}$ in a humidified atmosphere with $5 \% \mathrm{CO}_{2}$. Tryptase was used along with low molecular weight heparin (Sigma) with a molar ratio of 1.2:1.

Methylthiazole terazolium assay. MDA-MB-231 cells $\left(3 \times 10^{3}\right.$ cells/well) were seeded in 96-well plates and cultured overnight. After 6-h serum starvation, the cells were incubated with $500 \mathrm{pmol} / 1$ tryptase at different $\mathrm{pH}(6.0,6.5,7.0$ or 7.5$)$ for 12,24 or $36 \mathrm{~h}$. Twenty microliters of MTT (5 g/l) were added to each well and incubated for additional $4 \mathrm{~h}$. The supernatant was then removed. The reaction was stopped by adding $150 \mu 1$ dimethyl sulfoxide per well. The optical density was measured at $492 \mathrm{~nm}$ with a microplate reader.

In vitro cell invasion and migration assays. In vitro invasion assay was performed in Transwell ${ }^{\mathrm{TM}}$ Permeable Supports with porous filters $(8-\mu \mathrm{m}$ pore size) according to the manufacturer's instruction. The upper surface of the filter was coated with $25 \mu 1$ matrigel for $30 \mathrm{~min}$ at $37^{\circ} \mathrm{C}$. Cells $\left(2 \times 10^{4}\right)$ suspended in the medium containing $2 \%$ FBS with different concentrations of tryptase $(0,50,500$ and $1000 \mathrm{pmol} / 1$, respectively) were carefully added onto the upper surface of the transwell. After 12-, 24- and 36-h incubation at $\mathrm{pH} 7.0$, the filter was gently removed from the chamber. The cells on the upper surface were removed with a cotton swab. Cells that had passed through the matrigel and attached themselves to the lower surface of the filter were fixed with methanol and stained with Gimsa. Cells in 5 randomly selected microscopic fields (x200) per filter were counted.

To determine the effect of tryptase on cell migration, cells $\left(2 \times 10^{5}\right)$ were seeded onto the transwell not being coated with Matrigel. Cells on the lower surface was measured after being treated with tryptase $(0,50,500$ and $1000 \mathrm{pmol} / 1$, respectively) for $2 \mathrm{~h}$.

Gelatin zymography. Gelatin zymography was performed to evaluate Matrix metallopeptidase-2 (MMP-2) expression as previously described (8). The samples were subjected to SDS-polyacrylamide gel electrophoresis on $8 \%$ gels containing $1 \%$ gelatin. After electrophoresis, the gels were washed sequentially in $2.5 \%$ Triton $\mathrm{X}-100$ solution for $1 \mathrm{~h}$ and in $\mathrm{pH}$ 7.4 Tris-HCl buffer twice for $10 \mathrm{~min}$ with continuous shaking at room temperature. The gels were then incubated in $\mathrm{pH}$ 7.4 Tris- $\mathrm{HCl}$ buffer supplemented with $1 \%$ Triton $\mathrm{X}-100,5 \mathrm{mM} \mathrm{CaCl}$, and $0.02 \% \mathrm{Na}_{3} \mathrm{~N}$ for $18 \mathrm{~h}$ at $37^{\circ} \mathrm{C}$. The gels were stained with $0.1 \%$ Coomassie Brilliant Blue R-250. ProMMP-2 and active MMP-2 at bands of 72 and $62 \mathrm{kDa}$ respectively, were quantified by densitometry.

Statistical analysis. Data are presented as means \pm standard deviation. ANOVA and Student-Newman-Keuls tests were used for multiple comparisons and a value of $\mathrm{P}<0.05$ was considered significant.

\section{Results}

Morphometric analysis of tryptase in breast cancer lesions. The morphometric analysis of the immunohistochemically stained TMA showed that the ratios of tryptase-positive area to total sample area were $1.13 \pm 0.20 \%$ and $0.18 \pm 0.06 \%$ in peritumoral and normal breast tissues (Fig. 1A). The ratios were $0.82 \pm 0.09 \%, 1.92 \pm 0.46 \%$ and $2.25 \pm 0.27 \%$ in peritumoral tissue of grade 1, 2 and 3 breast cancer with lymph node metastasis, and $1.14 \pm 0.29 \%$ and $0.46 \pm 0.15 \%$ in peritumoral tissue of grade 1 and 2 breast cancer without lymph node metastasis, respectively (Fig. 1C). All grade 3 breast cancer patients had lymph node metastasis. The result showed the peritumoral tryptase expression in grade 3 breast cancer was significantly higher than that in grade 1 or grade 2 breast cancer (Fig. 1B). As shown in Fig. 1D, tryptase staining in peritumoral tissue with lymph node metastasis was more 

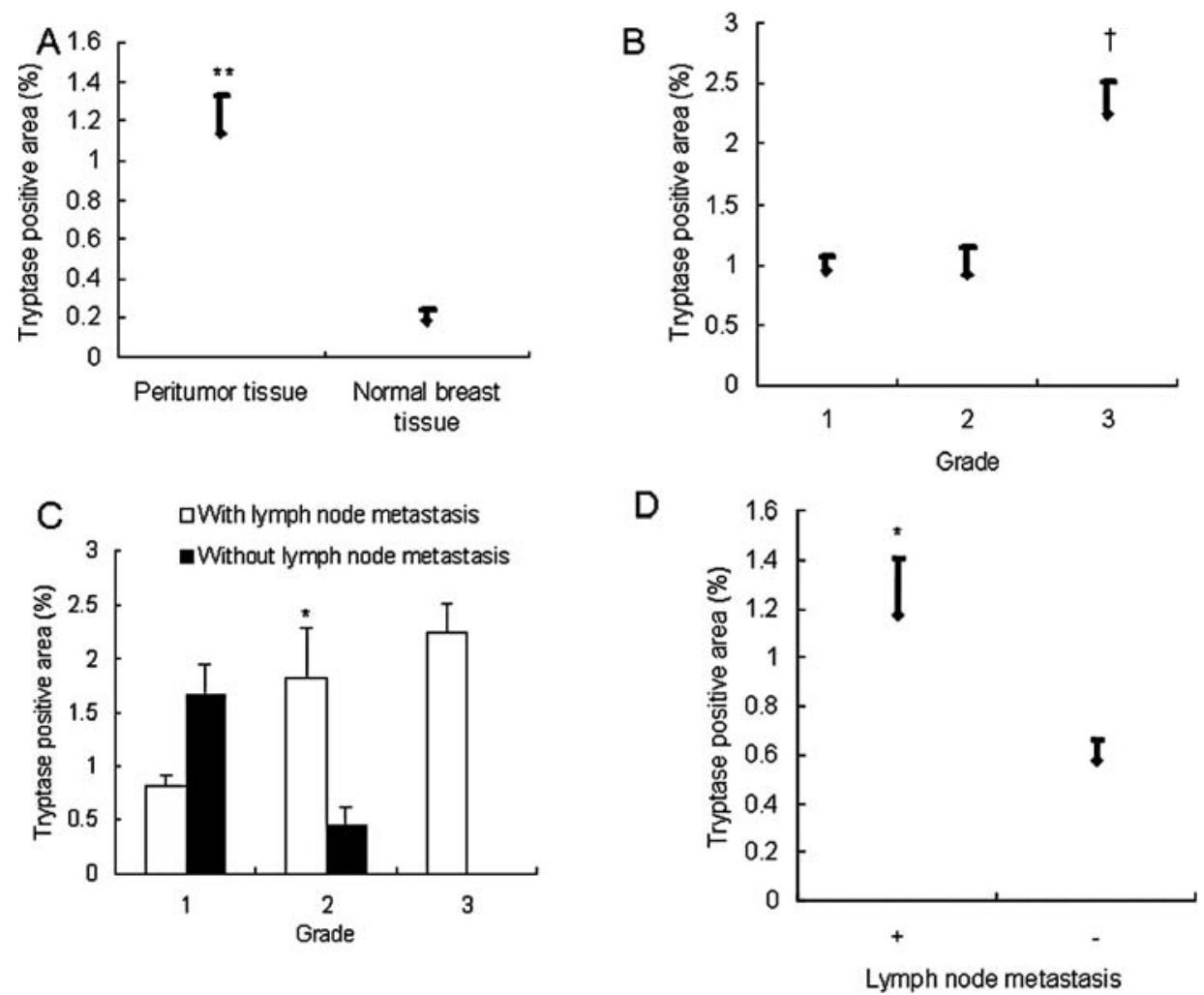

Figure 1. Morphometric analysis of tryptase-positive area. The ratio of the tryptase-positive and total sample areas of the peritumoral and normal breast tissues (A), the peritumor tissue of grades 1,2 and 3 of breast cancer (B), the peritumor tissue of grades 1,2 and 3 of breast cancer with and without lymph node metastasis $(\mathrm{C})$, and the peritumor tissue of breast cancer with and without lymph node metastasis (D), respectively. * and $* *$ represents $\mathrm{P}<0.05$ and $\mathrm{P}<0.001$ between the two groups. $\dagger$ represents $\mathrm{P}<0.05$, grade 3 vs. grade 1 or grade 2 .
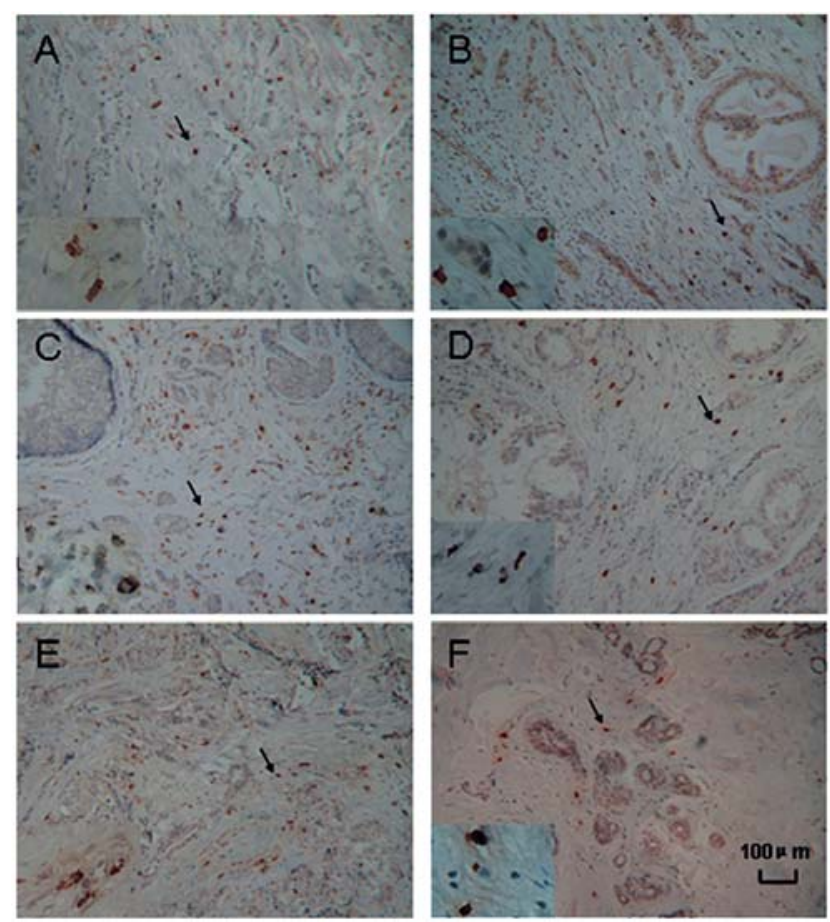

Figure 2. The representative images of tryptase staining. Tissue microarray of breast cancer and normal breast samples were immunohistochemically stained with tryptase antibodies. (A) Peritumoral tissue of grade 1 without lymph node metastasis. (B) Peritumoral tissue of grade 1 with lymph node metastasis. (C) Peritumoral tissue of grade 2 without lymph node metastasis. (D) Peritumoral tissue of grade 2 with lymph node metastasis. (E) Peritumoral tissue of grade 3 with lymph node metastasis. F, Normal breast tissue. intensive than that in peritumoral tissue without lymph node metastasis. The representative images of tryptase staining are shown in Fig. 2.

Effect of tryptase on the proliferation of MDA-MB-231 cells at different $p H$. Breast cancer is divided into grades 1,2 and 3 based on the frequency of cell mitosis, tubule formation and nuclear pleomorphism. These histological features represent the rate of cell proliferation. According to our TMA examination, there was more tryptase staining in the peritumoral area of grade 3 than grade 1 or grade 2 breast cancer. It is not known if the higher tryptase is a result or a cause. Therefore, we examined the relationship between cell proliferation and the presence of tryptase. The study was performed at neutral and acidic $\mathrm{pH}$ because tissue $\mathrm{pH}$ is reduced at the site of injury and inflammation. MCs are involve in the regulation of tissue $\mathrm{pH}$ and the activity of tryptase is sensitive to acidic pH. MDA-MB-231 cells were incubated in DMEM containing 2\% FBS with or without tryptase $(500 \mathrm{pmol} / \mathrm{l})$ at $\mathrm{pH}$ of $6.0,6.5,7.0$ or 7.5 for 12,24 and $36 \mathrm{~h}$, respectively. The results showed that there was no significant difference in cell proliferation as measured by MTT converting activity between groups with and without tryptase treatment (data not shown).

Tryptase increases the invasion and migration of MDA-MB231 cells. To investigate the role of tryptase in the invasion of MDA-MB-231 cells, the cells on Matrigel-coated transwell were treated with different concentrations of tryptase 
Table II. Effects of different concentrations of tryptase on the invasion of MDA-MB-231 cells.

\begin{tabular}{lrrrr}
\hline & & \multicolumn{3}{c}{ Tryptase } \\
\cline { 3 - 5 } Time (h) & Control & $50 \mathrm{pmol} / 1$ & $500 \mathrm{pmol} / \mathrm{l}$ & $1 \mathrm{nmol} / 1$ \\
\hline 12 & $8.0 \pm 2.2$ & $10.4 \pm 1.5$ & $10.3 \pm 0.8$ & $15.4 \pm 2.0$ \\
24 & $16.2 \pm 5.1$ & $9.3 \pm 2.3$ & $34.0 \pm 1.5^{\mathrm{b}, \mathrm{c}}$ & $19.8 \pm 3.7$ \\
36 & $25.8 \pm 3.9$ & $36.3 \pm 4.0^{\mathrm{a}}$ & $53.2 \pm 2.9^{\mathrm{b}, \mathrm{c}}$ & $36.0 \pm 0.7^{\mathrm{a}}$ \\
\hline
\end{tabular}

Data represent the number of cells per field that migrated across the supporting transwell filter coated with Matrigel. ${ }^{\mathrm{a}} \mathrm{P}<0.05$ and ${ }^{\mathrm{b}} \mathrm{P}<0.01$ vs. control, respectively. ${ }^{\mathrm{c}} \mathrm{P}<0.01$ vs. $50 \mathrm{pmol} / \mathrm{l}$ or $1 \mathrm{nmol} / \mathrm{l}$.

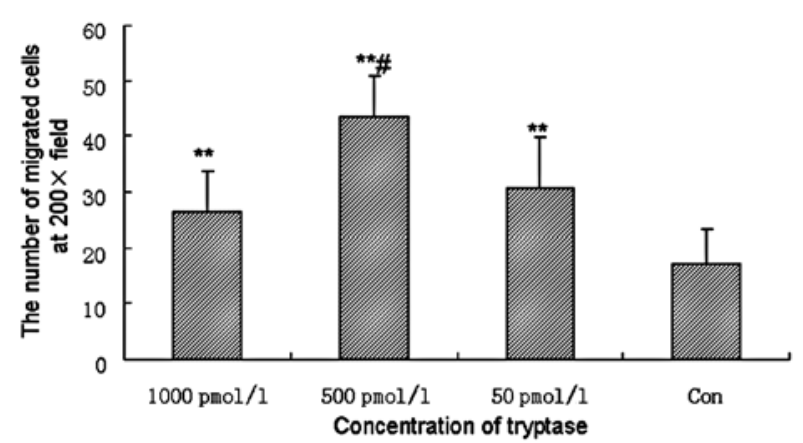

Figure 3. Effects of different concentrations of tryptase on the migration of MDA-MB-231 cells. ${ }^{* *} \mathrm{P}<0.01$ compared to control group. ${ }^{\text {" }} \mathrm{P}<0.01$ compared to $1000 \mathrm{pmol} / 1$ or $50 \mathrm{pmol} / 1$ group; $\mathrm{n}=3$.

(50, $500 \mathrm{pmol} / \mathrm{l}$, and $1 \mathrm{nmol} / 1$ tryptase, respectively) for 12,24 and $36 \mathrm{~h}$ at $\mathrm{pH} 7.0$. The $\mathrm{pH}$ was determined according to our preliminary study in which we found tryptase (500 pmol/1) increased the invasion of MDA-MB-231 breast cancer cells at $\mathrm{pH} 7.0$ but not at $\mathrm{pH}$ 6.0, 6.5 and 7.5 (data not shown). As shown in Table II, at $24 \mathrm{~h}$, the number of invaded cells in tryptase groups was significant higher than that in control group $(\mathrm{p}<0.01)$. The number of invaded cells in 500 pmol/l tryptase group was significant larger than that in control, $50 \mathrm{pmol} / \mathrm{l}(\mathrm{p}<0.01)$ or $1 \mathrm{nmol} / \mathrm{l}(\mathrm{p}<0.05)$ group. Similar effect of trypase on cell migration was observed using transwell without Matrigel coating (Fig. 3).

Effect of tryptase on the activation of MMP-2 released by cultured MDA-MB-231 cells. MMP-2 promotes the invasion of cancer and inflammatory cells. To determine whether MMP-2 is related to tryptase-induced cancer cell invasion, MDA-MB-231 cells were cultured with $500 \mathrm{pmol} / \mathrm{l}$ tryptase for $12-48 \mathrm{~h}$. The culture medium was then subjected to gelatin zymography. Two gelatinolytic bands were detected in the medium with molecular weights consistent with pro-MMP-2 (72 kDa) and activated MMP-2 (62 kDa). The activated MMP-2 levels of tryptase-treated cells were 1.1-, 6.9-, 2.1- and 2.5-fold of those in corresponding controls at

\section{A $\quad \frac{\text { Control }}{12 \mathrm{~h} 24 \mathrm{~h} 36 \mathrm{~h} 48 \mathrm{~h}} \frac{500 \text { pmoln Tryptase }}{12 \mathrm{~h} 24 \mathrm{~h} 36 \mathrm{~h} 48 \mathrm{~h}}$}
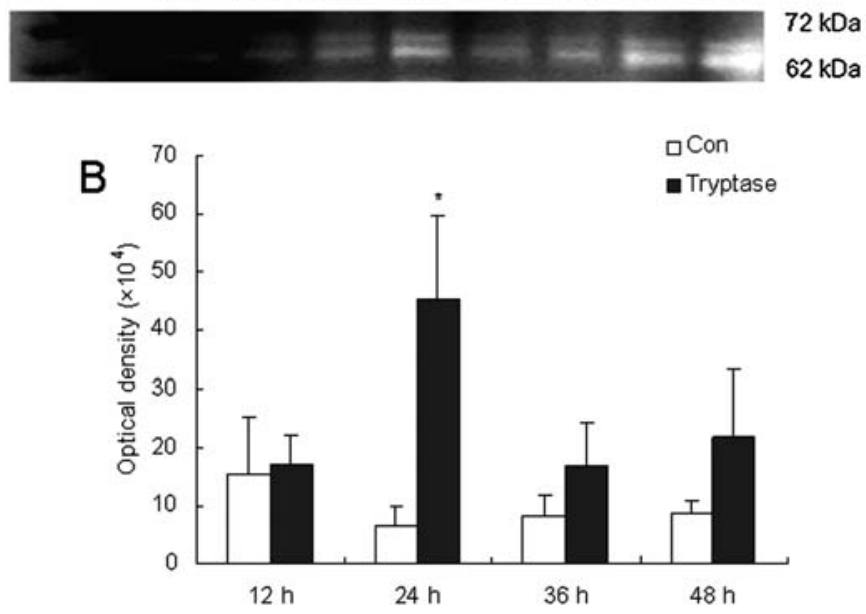

C

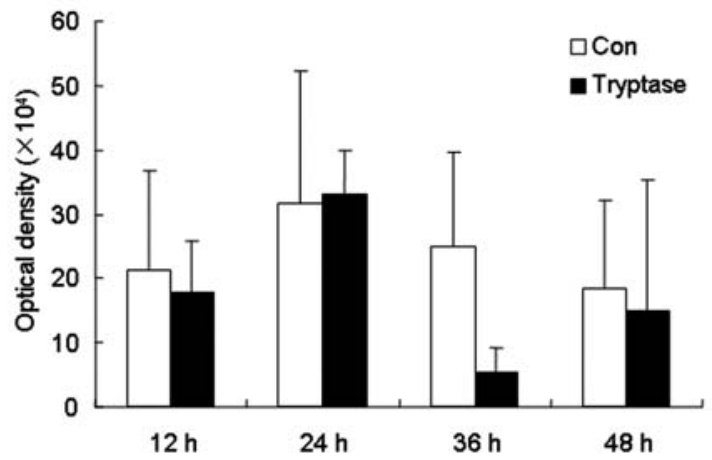

Figure 4. Tryptase increased the release of MMP-2 from cultured human MDA-MB-231 cells. MDA-MB-231 cells were incubated in the absence or presence of typtase $(500 \mathrm{pmol} / \mathrm{l})$ for $12-48 \mathrm{~h}$. The culture supernatants were then collected and subjected to gelatin zymography for MMP-2 and proMMP-2 measurement. (A) Tryptase increases the activation of MMP-2 from cultured human MD-MBA-231 cells. MD-MBA-231 cells were incubated in the absence or presence of typtase $(500 \mathrm{pmol} / \mathrm{l})$ for $12-48 \mathrm{~h}$. The optical density of MMP-2 (B) and pro-MMP-2 (C) in the stained gels was measured by densitometry. Data at $12,24,36$ and $48 \mathrm{~h}$ were shown. ${ }^{*} \mathrm{P}<0.05$ compared to control; $\mathrm{n}=5$.

$12,24,36$ and $48 \mathrm{~h}$. The change of pro-MMP-2 was not significant (Fig. 4).

\section{Discussion}

MCs are frequently found in peritumor tissue and play an important role in inflammation and cancer. Lebeau et al demonstrated that grade 3 breast cancer had more MC infiltration than grade 2 in breast cancer (9). MC tryptase is a tetrameric neutral serine protease with a molecular weight of $134 \mathrm{kD}$. It locates mainly in MCs of various tissues. Tryptase is increased in many cancer patients. For example, the serum level of tryptase is three-times higher in patients with breast cancer than in healthy people (10). However, whether tryptase is related to cancer metastasis is not known. In our morphometric analysis of TMA, tryptase increased and correlated with breast cancer grade and lymph node metastasis. Our studies using cultured MDA-MB-231 breast cancer cells further demonstrated that tryptase promotes 
cancer cell invasion, migration and the activity of MMP-2, but not cell proliferation. These results indicated that enhanced tryptase is correlated to the increased risk of metastasis.

The activity of tryptase is pH-dependent. It is completely inactivated at neutral $\mathrm{pH}$ in absence of heparin. Tryptase forms enzymatically active tetramers either in presence or absence of heparin at acidic pH (11). Hypoxia due to the imbalance in angiogenesis and tumor growth is a common pathophysiologic feature of most solid tumors including breast cancer. Hypoxia induces rapid MC degranulation $(12,13)$. Insufficient oxygen supply and waste removal as well as the acidic metabolites produced by lysosomal enzymes and released through the $\mathrm{MC}$ degranulation reduce the $\mathrm{pH}$ in the breast cancer microenvironment. The $\mathrm{pH}$-dependent characteristic of tryptase necessitates the examination of the enzyme's effects on the proliferation and migration of cancer cells at different $\mathrm{pH}$. Tryptase activation depends on acidic $\mathrm{pH}$ and the presence of heparin. We found the enzyme did not affect the proliferation of MDA-MB-231 breast cancer cells at $\mathrm{pH}$ ranging from 6.0 to 7.5 (data not shown) in the absence of heparin. The enzyme facilitated the transmembrane migration and invasion of the cells at $\mathrm{pH} 7.0$ but not other $\mathrm{pH}$ in the presence of heparin (Table II, Fig. 3). Because MCs also release significant amount of heparin, our results indicate that tryptase promotes cancer metastasis only when the cancer grows to a stage that the blood circulation fails to remove acidic substances from the cancer mass, consistent with our TMA examination in which we showed tryptase expression was higher in the fast growing grade 3 breast cancer.

The degradation of extracellular matrix (ECM) and components of the basal membrane play an important role in breast cancer invasion and metastasis $(14,15)$. MCs contribute to this process by releasing neutral proteases such as tryptase. This enzyme may act indirectly by activating the matrix metalloproteinases (MMPs). MMPs are a large family of proteolytic enzymes. They degrade many components of the ECM in the breast cancer (16). Among MMPs, MMP-2 is especially important due to its unique capability in degrading type IV collagen. Type IV collagen is a major component of the basement membrane that cancer cells have to breach in order to enter the stroma during the initial stage of tumor invasion $(17,18)$. Yamamoto et al reported that tryptase activates MMP-2 released from corneal fibroblasts (19). The present study demonstrated that tryptase increased the amount of activated MMP-2 in the medium of cultured MDA-MB231 cells. We did not observe a proportional decrease in proMMP-2. This may be due to responsive increase of proMMP-2 synthesis. This result is consistent with our finding that tryptase facilitated the transmembrane migration.

In conclusion, the increased MC tryptase in the peritumoral tissue may promote breast cancer invasion.

\section{Acknowledgements}

This study was supported by grant from the National Nature Science Foundation of China (No. 30830050, 30470689 and 30771003) and National Key Basic Research Program (2009CB521907), National key discipline program 211XK20 of China and Shanghai Pujian program (08PJ14025). The authors thank Dr Shunlin Ren for his important technological advice.

\section{References}

1. Irani AM, Bradford TR, Kepley CL, Schechter NM and Schwartz LB: Detection of MCT and MCTC types of human mast cells by immunohistochemistry using new monoclonal anti-tryptase and anti-chymase antibodies. J Histochem Cytochem 37: 1509-1515, 1989 .

2. Toth-Jakatics R, Jimi S, Takebayashi S and Kawamoto N: Cutaneous malignant melanoma: correlation between neovascularization and peritumor accumulation of mast cells overexpressing vascular endothelial growth factor. Hum Pathol 31: 955-960, 2000.

3. Kankkunen JP, Harvima IT and Naukkarinen A: Quantitative analysis of tryptase and chymase containing mast cells in benign and malignant breast lesions. Int J Cancer 72: 385-388, 1997.

4. Iamaroon A, Pongsiriwet S, Jittidecharaks S, Pattanaporn K, Prapayasatok S and Wanachantararak S: Increase of mast cells and tumor angiogenesis in oral squamous cell carcinoma. J Oral Pathol Med 32: 195-199, 2003.

5. Wedemeyer J and Galli SJ: Decreased susceptibility of mast cell-deficient $\mathrm{Kit}(\mathrm{W}) / \mathrm{Kit}(\mathrm{W}-\mathrm{v})$ mice to the development of 1 , 2-dimethylhydrazine-induced intestinal tumors. Lab Invest 85: 388-396, 2005

6. Schwartz LB: Tryptase: a mast cell serine protease. Methods Enzymol 244: 88-100, 1994.

7. Schwartz LB, Bradford TR, Rouse C, Irani AM, Rasp G, Van der Zwan JK and Van der Linden PW: Development of a new, more sensitive immunoassay for human tryptase: use in systemic anaphylaxis. J Clin Immunol 14: 190-204, 1994.

8. Nagano T, Hao JL, Nakamura M, Kumagai N, Abe M, Nakazawa T and Nishida T: Stimulatory effect of pseudomonal elastase on collagen degradation by cultured keratocytes. Invest Ophthalmol Vis Sci 42: 1247-1253, 2001.

9. Lebeau A, Muller-Aufdemkamp C, Allmacher C, Sauer U, Nerlich A, Lichtinghagen R and Lohrs U: Cellular protein and mRNA expression patterns of matrix metalloproteinases$2,-3$ and -9 in human breast cancer: correlation with tumour growth. J Mol Histol 35: 443-455, 2004.

10. Samoszuk M and Corwin MA: Mast cell inhibitor cromolyn increases blood clotting and hypoxia in murine breast cancer. Int J Cancer 107: 159-163, 2003.

11. Ren S, Lawson AE, Carr M, Baumgarten CM and Schwartz LB: Human tryptase fibrinogenolysis is optimal at acidic $\mathrm{pH}$ and generates anticoagulant fragments in the presence of the antitryptase monoclonal antibody B12. J Immunol 159: 3540-3548, 1997.

12. Binley K, Askham Z, Martin L, Spearman H, Day D, Kingsman S and Naylor S: Hypoxia-mediated tumour targeting. Gene Ther 10: $540-549,2003$.

13. Steiner DR, Gonzalez NC and Wood JG: Mast cells mediate the microvascular inflammatory response to systemic hypoxia. J Appl Physiol 94: 325-334, 2003.

14. Yoon SO, Park SJ, Yun CH and Chung AS: Roles of matrix metalloproteinases in tumor metastasis and angiogenesis. J Biochem Mol Biol 36: 128-137, 2003.

15. Westermarck J and Kahari VM: Regulation of matrix metalloproteinase expression in tumor invasion. FASEB J 13: 781-792, 1999.

16. Curran S and Murray GI: Matrix metalloproteinases in tumour invasion and metastasis. J Pathol 189: 300-308, 1999.

17. Kurizaki T, Toi M and Tominaga T: Relationship between matrix metalloproteinase expression and tumor angiogenesis in human breast carcinoma. Oncol Rep 5: 673-677, 1998.

18. Papathoma AS, Petraki C, Grigorakis A, Papakonstantinou H, Karavana V, Stefanakis S, Sotsiou F and Pintzas A: Prognostic significance of matrix metalloproteinases 2 and 9 in bladder cancer. Anticancer Res 20: 2009-2013, 2000.

19. Yamamoto K, Kumagai N, Fukuda K, Fujitsu Y and Nishida T: Activation of corneal fibroblast-derived matrix metalloproteinase-2 by tryptase. Curr Eye Res 31: 313-317, 2006. 